\title{
Pre-harvest application of salicylic acid influence physicochemical and quality characteristics of 'Chimarrita' peaches during cold storage
}

\author{
Jakellinye Miranda1*, Suélen Braga de Andrade², Andressa Vighi Schiavon², \\ Pedro Luis Panisson Kaltbach Lemos ${ }^{3}$, Cláudia Simone Madruga Lima1, Marcelo Barbosa Malgarim² \\ ${ }^{1}$ Federal University of Fronteira Sul, Rodovia BR 158 - Km 405, CEP 85301-970 Laranjeiras do Sul, PR - Brazil, ${ }^{2}$ Federal University of \\ Pelotas, Campus Universitário, S/N - CEP 96160-000, ${ }^{3}$ KULeuven TC Ghent, Gebroeders de Smetstraat 1, 9000. Gent - Belgium
}

\section{A B S T R A C T}

\begin{abstract}
Peach is a climacteric highly-perishable fruit whose post-harvest preservation relies largely on cold storage. The combination of the last with other technologies allows to extend the shelf life of this product. One alternative is the utilization of salicylic acid, a natural compound involved in many physiological phenomena such as resistance against diseases and ripening. Considering these facts, the objective of the present work was to evaluate the effect of pre-harvest application of salicylic acid solutions on the quality of 'Chimarrita' peaches during post-harvest cold storage. The experiment was conducted at the Federal University of Pelotas/RS, in the campus of Capão do Leão/RS - Brazil. The application of salicylic acid solutions was performed by direct pulverization on the fruits, 30 days prior to harvest. The concentrations were: 0,0 (control); 1,$0 ; 1,5$; and 2,0 mM. After harvest, the fruits were stored in a cold chamber at $1,0 \pm 0,5^{\circ} \mathrm{C}$ and $85-90 \% \mathrm{RH}$, for 30 days. The analyses were performed at the following cold storage periods (plus 2 days at room temperature of $20^{\circ} \mathrm{C}$ to all treatments, in order to simulate commercialization conditions): $10(+2)$ days; $20(+2)$ days; e $30(+2)$ days. The variables evaluated were: mass loss (\%); flesh firmness (N); DA index; color ( $\mathrm{L}, \mathrm{a}^{*}, \mathrm{~b}^{*}$ and hue angle); wooliness incidence (\%); rot incidence (\%); total soluble solids ( $\left.{ }^{\circ} \mathrm{Brix}\right) ; \mathrm{pH}$; titrable acidity ( $\%$ of organic acids); and ratio. The salicylic acid doses and/or the cold storage periods had significant effects on all the evaluated parameters. For most of the parameters analyzed, the intermediate dosis of $1 \mathrm{mM}$ (and also $1,5 \mathrm{mM}$ ) of salicilic acid showed the most promising results. Therefore, the application of salicylic acid solutions 30 days prior to harvest is a technique which can be combined to cold storage in order to shift the quality and the shelf-life of 'Chimarrita' peaches.
\end{abstract}

Keywords: Peach; Physicochemical; Prunus persica (L.); Quality

\section{INTRODUCTION}

The peach tree is a native species from China, belonging to the group of the stone fruits. Brazil is the $13^{\text {th }}$ biggest peach producer worldwide, with a production of 216.000 tons. Among its physiological characteristics, the climacteric behavior is of special concern for the post-harvest management, because the fruit continues its ripening processes after harvest, being a perishable product with short shelf-life (Kerbauy, 2012).

Many factors during the post-harvest handling might increase the ethylene production and the respiration rate - both physiological phenomena are directly linked to significant losses during distribution and commercialization. Important examples of these factors are: elevated temperatures (Barreto et al. 2016a); mechanical injuries (Kasat et al. 2007); and diseases. As highlighted by Parisi et al. (2015), diseases represent the main cause of product losses.

Cold storage is an important technology used to extend the shelf-life of peaches (Chitarra and Chitarra, 2005). Nevertheless, just the storage at low temperatures is not enough for an efficient preservation, what requires combinations of other technologies.

Salicylic acid is a phenolic compound involved in many plant physiological processes (Catinot, 2008; Dempseya, 2011; Seyfferth and Tsuda, 2014). As described by Colli (2012), the name of this molecule was given after being found in the bark of the weeping willow (Salix babilonica), even though it is ubiquitous in the plant kingdom and can

\footnotetext{
*Corresponding author:

Jakellinye Miranda, Federal University of Fronteira Sul, Rodovia BR 158 - Km 405, CEP 85301-970 Laranjeiras do Sul, PR - Brazil.

E-mail: jakelynye@gmail.com
}

Received: 03 December 2018; $\quad$ Accepted: 30 January 2019 
be found in different plant tissues, such as leaves and reproductive structures.

When applied exogenously, one of the roles attributed to salicylic acid in plants is to work as a signaling molecule which induces the expression of genes against the attack of microorganisms such as fungi, bacteria, and viruses (Ferrareze, 2014). Furthermore, this molecule has been considered a new potential alternative to reduce senescence in some plant species, as it is related to the reduction of ACC oxidase activity, enzyme which catalyzes the formation of ethylene (Borsatti, 2014; Cavasini, 2013).

Many studies on post-harvest technologies for many cultures such as acerola (Sanches, et al. 2015), black-berry (Borsatti et al. 2015), persimmon (Khademi et al. 2012; Miranda et al. 2017), orange (Rossarolla et al. 2012), strawberry (Robaina, 2013; Coltro et al. 2014), and peach (Silva et al. 2016; Loy et al. 2016) employed salicylic acid. These studies indicate that this compound has a potential role on the reduction of post-harvest losses for a broad range of cultures, with easy application and at a low cost (Ding et al. 2001).

Considering what was discussed above, the objective of this research was to evaluate the effect of pre-harvest application of salicylic acid on 'Chimarrita' peaches, with regard to physicochemical characteristics and rot incidence after cold storage and commercialization simulation.

\section{MATERIALS AND METHODS}

The plant material employed in the experiments was peaches of the cultivar 'Chimarrita', in the cycle 2013/2014, grown in the didactic orchard of the UFPel (Pomar Didático do Centro Agropecuário da Palma/Federal University of Pelotas), located in the municipality of Capão do Leão, RS, Brazil, latitude $31^{\circ} 52^{\prime} 00^{\prime \prime} \mathrm{S}$, longitude $52^{\circ}$ 21 '24" W, and altitude 13,24 meters. The soil belongs to the Camaquã unit, being moderately deep, with medium texture on the horizon A, clay in B, and classified as Ultisol (Reisser Junior et al. 2008). The local climate is characterized as temperate and humid with hot summers, "Cfa" according to the Köppen classification. The region has an annual temperature and precipitation average of $17.9^{\circ} \mathrm{C}$ and $1500 \mathrm{~mm}$, respectively.

The application of salicylic acid solutions was performed at 30 days prior to harvest. Four groups of three neighbouring plants were randomly selected within the orchard. Each of the four groups of three plants were isolated one from each other, by respecting and interval of 2 plants which received no treatment. Each group received each of the four treatments on all the fruits of the plant. A manual backpacktype sprayer was used to completely cover the fruit surfaces with the spray solutions. The following concentrations were applied on the peaches with the addition of $0,5 \mathrm{~mL} \cdot \mathrm{L}^{-1}$ spreader sticker to the solution: T1 $-0,0 \mathrm{mM}$ of salicylic acid (control); T2 - 1,0 mM of salicylic acid; T3 - 1,5 mM of salicylic acid; and T4 - 2,0 mM of salicylic acid.

Thirty days after the salicylic acid application, the fruits were manually harvested, by random selection throughout all the branches of the plant. As selection criteria, just fruits at physiological maturation stage were included, and those which presented mechanical injuries, defects, and attacks of insects or pathogens were excluded. The fruits were then stored in a cold chamber at $1,0 \pm 0,5^{\circ} \mathrm{C}$ and $85-90 \% \mathrm{RH}$, for 30 days. The analyses were performed at the following cold storage periods (plus 2 days at room temperature, $20^{\circ} \mathrm{C}$, to all treatments, in order to simulate commercialization conditions): $10(+2)$ days; $20(+2)$ days; e $30(+2)$ days.

The independent variables which were evaluated are described next. Mass loss (\%) - determined as the difference between initial and final masses, divided by the initial mass for each replicate: (initial mass - final mass/ initial mass) x 100). DA Index - obtained with DA-meter 53500 , which generates the index as a difference of absorbance at the wave-lengths 670 and $720 \mathrm{~nm}$ (chlorophyll A peak). Flesh firmness $(\mathrm{N})$ - obtained with a bench penetrometer and expressed in Newtons. Soluble solids ( ${ }^{\circ}$ Brix $)$ - measured by destructive method, with digital refractometer with automatic temperature compensation. $\mathrm{pH}-$ measured with digital $\mathrm{pHmeter}$ with automatic temperature compensation. Titrable acidity ( $\%$ of organic acids) - obtained by titration until neutralization, expressed as \% of organic acids. Ratio calculated as the ratio between total soluble solids and titrable acidity. Rot incidence (\%) - obtained by visual evaluation of fruits with typical lesions from fungi or bacteria; expressed as percentage of fruits presenting lesions larger than $5 \mathrm{~mm}$. Wooliness incidence (\%) obtained by visual evaluation of fruit appearance upon cutting; expressed as percentage of fruits presenting wooliness. Color ( $\mathrm{L}^{*} \mathrm{a} * \mathrm{~b}^{*}$ and $\left.{ }^{\circ} \mathrm{Hue}\right)$ - measured by reading the equatorial surface of the fruits with a colorimeter Chroma meter CR-400 (Konica Minolta) which expresses the color by the system CIE L*a*b*. The analyses were performed at LabAgro, UFPel.

The experimental design employed was completely randomized, with 4 replicates, 15 peaches per experimental unit, and a $4 \times 3$ factorial design, comprising 4 levels of salicylic acid and 3 levels of storage period. The data were subject to Analyses of Variance (ANOVA) and the variables 
displaying significant differences $(p \leq 0,05)$ followed to regression and Tukey test at $5 \%$ of significance.

\section{RESULTS AND DISCUSSION}

For mass loss, there was interaction between the independent variables - storage periods and salicylic acid levels. A reduction in mass loss was observed for the treatments with 1 and $1,5 \mathrm{mM}$ of salicylic acid at 30 days of cold storage. Similar results were found for 'Elberta' peaches treated with salicylic acid and refrigerated, which showed significant lower mass losses with the use of salicylic acid concentrations of 1,0 and $2,0 \mathrm{mM}$ (Khademi and Ershadi, 2013). This was an expected outcome for this kind of plant material, because the overall mass loss (mainly water loss and dry matter loss by respiration) could be mitigated by the salicylic acid utilization (Ben-Yehoshua and Rodov, 2005). For the other storage periods of 10 and 20 days, the application of different doses of salicylic acid did not improve (reduce) the mass loss in the present study.

The firmness (Figure 1) showed an interaction between the independent variables and was generally reduced by the application of salicylic acid solutions at 10 and 30 days of cold storage, when compared with the control $(0,0 \mathrm{mM})$. This was especially true for the treatment with $1,5 \mathrm{mM}$ at 30 days. The intermediate concentrations of 1 and $1,5 \mathrm{mM}$ resulted in lower firmness at 20 days $(4,0$ and $4,25 \mathrm{~N}$, respectively) and 30 days (2,5 $\mathrm{N}$ and $1,75 \mathrm{~N}$ respectively). However, the highest values were observed at 20 days within all the different level of salicylic acid. Silva et al. (2016), observed no effect of salicylic acid doses on flesh firmness in 'Kampai' peaches stored at room temperature, but did observe a reduction in firmness along the storage time.

For the color parameter L, there were no significant differences. The color parameters $a^{*}$ and $b^{*}$ showed significant differences $(p \leq 0,05)$ just for the independent variable storage period. The $\mathrm{a}^{*}$ values increased slightly along the storage time, what can be translated as an increase in the red color of the epidermis. The $b^{*}$ values showed a very small variation and stood within the zone of the yellowish. During the ripening of climacteric fruits, an increased production of ethylene and the consequent activation of enzymes cause several biochemical reactions, such as the degradation of chlorophyll and the accumulation of carotenoids (Kerbauy, 2012). Important changes of color are caused by the activity of polyphenoloxidase. This enzyme (and phenolic compounds - the substrate) are "directly responsible for the enzymatic browning reactions in damaged fruits during postharvest handling and processing. The reactions produce undesirable changes in color, flavor, and nutritive value of the product" (Lee et al. 1990).

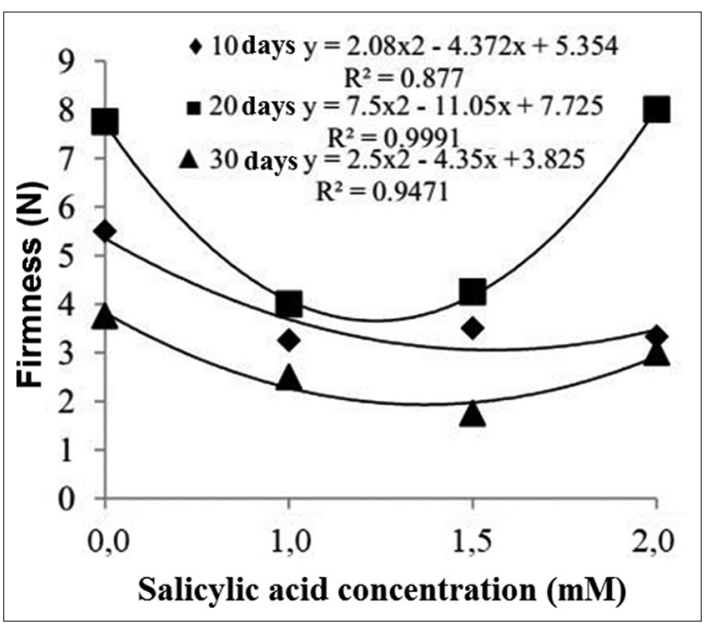

Fig 1. Firmness (N) of 'Chimarrita' peaches, cycle 2013/2014, treated with different concentrations of salicylic acid - 0,0,1,0,1,5, and $2,0 \mathrm{mM}$ - and cold storage $-10,20$, and 30 days (+ 2 days at $20^{\circ} \mathrm{C}$ to simulate commercialization), Pelotas/RS - Brazil.

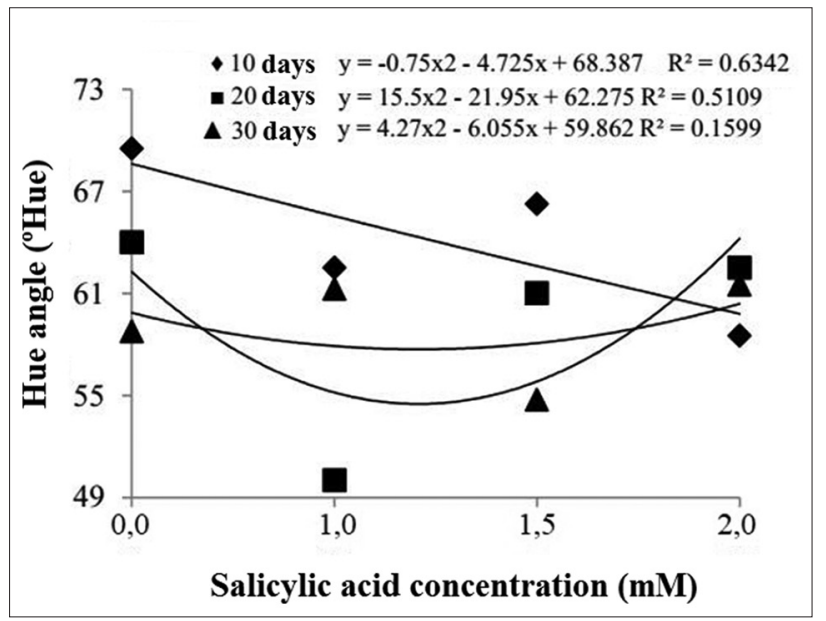

Fig 2. Hue angle (Hue) of 'Chimarrita' peaches, cycle 2013/2014, treated with different concentrations of salicylic acid - $0,0,1,0,1,5$, and $2,0 \mathrm{mM}$ - and cold storage $-10,20$, and 30 days ( +2 days at $20 \mathrm{C}$ to simulate commercialization), Pelotas/RS - Brazil.

The hue angle values ( ${ }^{\circ} \mathrm{Hue}$ ) (Figure 2) showed interaction between independent variables. Infante et al. (2008) state that this parameter is important to evaluate the degree of peach ripeness, since its values decrease along fruit ripening. This behavior was observed in other researches conducted with other varieties of peaches, also treated with salicylic acid (Andrade et al. 2015; Farias et al. 2016; Silva et al. 2016).

For DA index, there was no interaction between the independent variables, but there were significant differences for each of them independently. A clear decline of the DA index can be observed as the storage time proceeds (Figure 3). This variable is directly related to the fruit ripeness, since it is calculated from the absorbance of chlorophyll; hence, the higher the value, the higher the 


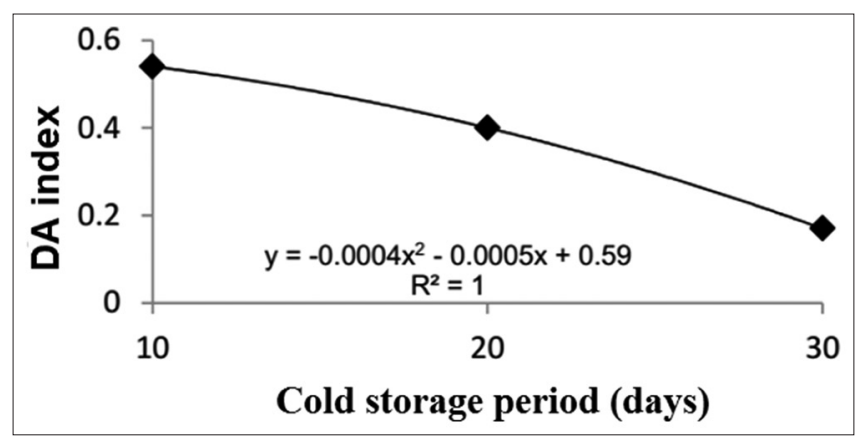

Fig 3. DA index of 'Chimarrita' peaches, cycle 2013/2014, treated with different concentrations of salicylic acid - 0,0,1,0,1,5, and 2,0 mM - and cold storage $-10,20$, and 30 days ( +2 days at $20 \mathrm{C}$ to simulate commercialization), Pelotas/RS - Brazil.

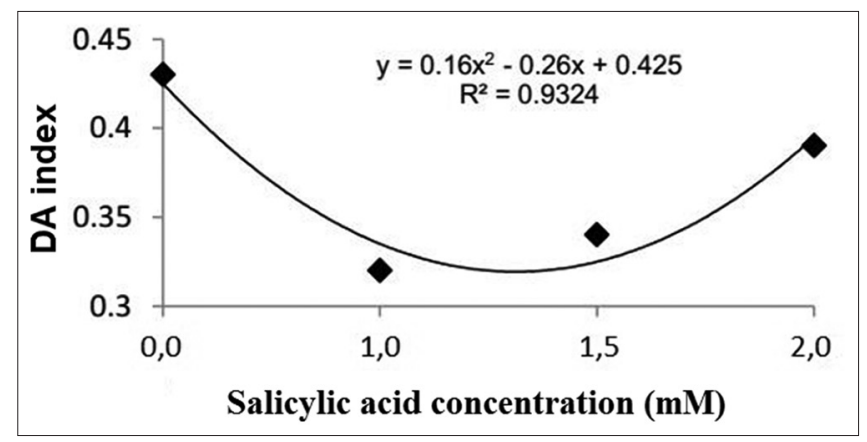

Fig 4. DA index of 'Chimarrita' peaches, cycle 2013/2014, treated with different concentrations of salicylic acid - 0,0, 1,0, 1,5, and 2,0 mM - and cold storage $-10,20$, and 30 days $(+2$ days at $20 \mathrm{C}$ to simulate commercialization), Pelotas/RS - Brazil.

chlorophyll content in the tissue, the more unripe the fruit (Barreto et al. 2016b; Farias et al. 2016a).

With relation to levels of salicylic acid, the control $(0,0 \mathrm{mM})$ presented higher average DA index values. The treatments with intermediate concentrations of salicylic acid $(1,0$ and $1,5 \mathrm{mM}$ ) resulted in lower values for this variable. As explained by Silva et al. (2016), a DA index close to zero indicate elevated ripeness. Therefore, even though there were significant differences between the treatments, all the fruits could be considered ripe.

Wooliness is one of the main types of chill injuries in stone fruits. Just the storage periods had a significant effect on this variable. At 10 and 20 days of storage, no wooliness was observed. After 30 days, an average of $39,06 \%$ of the fruits presented wooliness (Figure 5). Similar results were found by Pinheiro et al. (2014) with 'Chimarrita' peaches stored cold for 30 days plus 3 days at $25^{\circ} \mathrm{C}$. In this case, the wooliness incidence was also higher at $30(+3)$ days of storage.

Rot incidence (Figure 6) was influenced by salicylic acid applications, but not by storage periods. The concentrations of $0,0,1,5$, and $2,0 \mathrm{mM}$ did not differ, and the lowest and

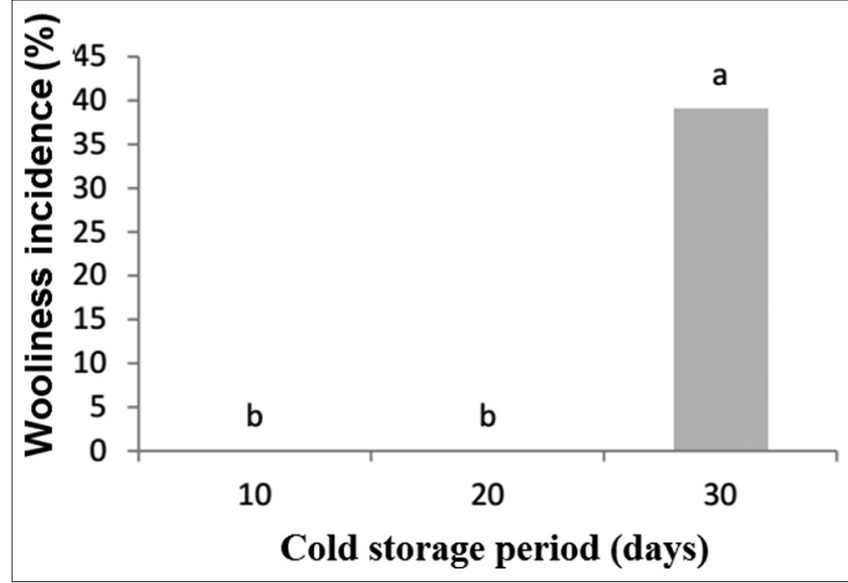

Fig 5. Wooliness incidence (\%) in 'Chimarrita' peaches, cycle $2013 / 2014$, treated with different concentrations of salicylic acid - 0,0, $1,0,1,5$, and $2,0 \mathrm{mM}$ - and cold storage $-10,20$, and 30 days (+ 2 days at $20 \mathrm{C}$ to simulate commercialization), Pelotas/RS - Brazil. Averages followed by the same letter did not differ in a Tukey test at $5 \%$ of significance.

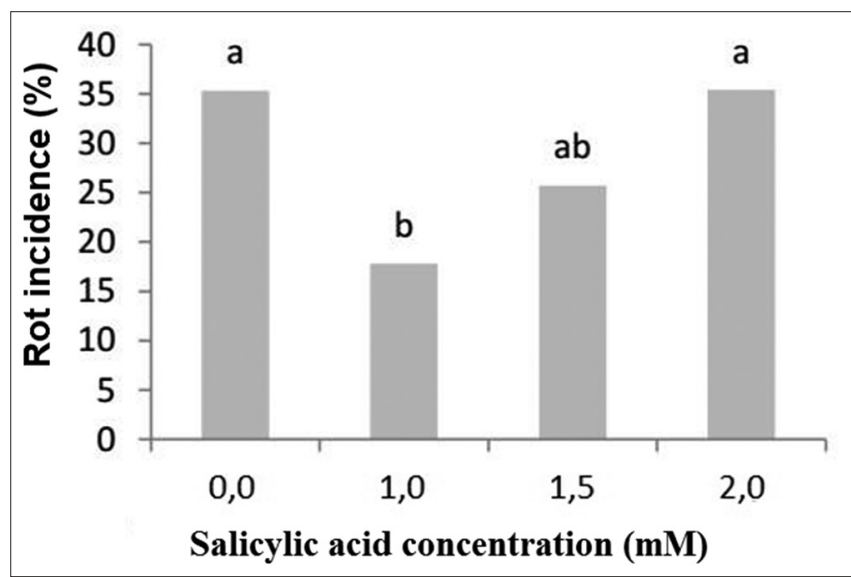

Fig 6. Rot incidence (\%) in 'Chimarrita' peaches, cycle 2013/2014, treated with different concentrations of salicylic acid - 0,0,1,0,1,5, and $2,0 \mathrm{mM}$ - and cold storage $-10,20$, and 30 days ( +2 days at $20^{\circ} \mathrm{C}$ to simulate commercialization), Pelotas/RS - Brazil. Averages followed by the same letter did not differ in a Tukey test at $5 \%$ of significance.

the highest concentrations $(0,0$ and $2,0 \mathrm{mM})$ presented very similar average values of $35.33 \%$ e $35.41 \%$, respectively. The treatments with 1,0 $\mathrm{mM}$ of salicylic acid showed a remarkable low average of $17,82 \%$, roughly a $50 \%$ lower rot incidence than the control $(0,0 \mathrm{mM})$.

A research made by Farias et al. (2016b) with 'Chiripá' peaches, the post-harvest application of $2,0 \mathrm{mM}$ of salicylic acid reduced the diameter of fungal lesions. Silva et al. (2016) also found that salicylic acid was efficient to control the post-harvest rot in 'Kampai' peaches stored at room temperature, obtaining rot incidences of 37,62 and 28,34\% for concentrations of 1,0 and $3,0 \mathrm{mM}$, respectively. These values are similar to those obtained for treatments with 0,0 and 2,0 $\mathrm{mM}$ of salicylic in the present study. 


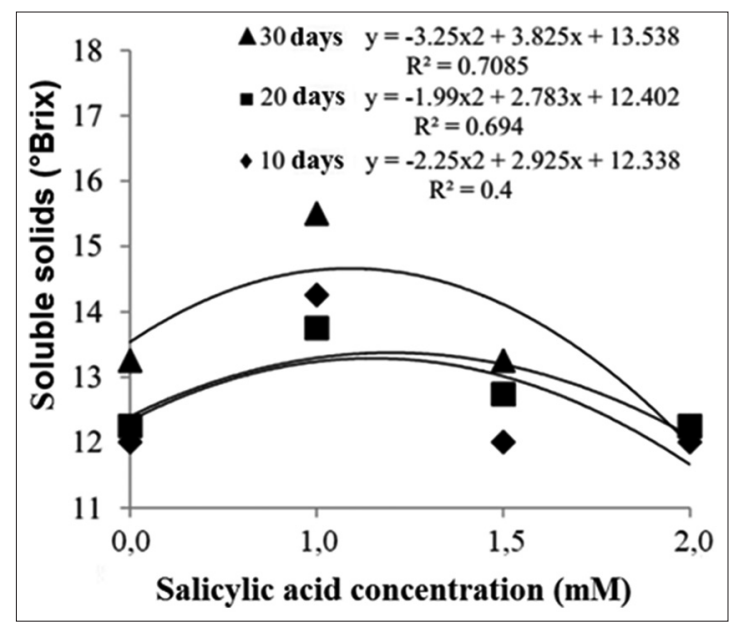

Fig 7. Soluble solids (Brix) of 'Chimarrita' peaches, cycle 2013/2014, treated with different concentrations of salicylic acid - $0,0,1,0,1,5$, and $2,0 \mathrm{mM}$ - and cold storage $-10,20$, and 30 days ( +2 days at $20 \mathrm{C}$ to simulate commercialization), Pelotas/RS - Brazil.

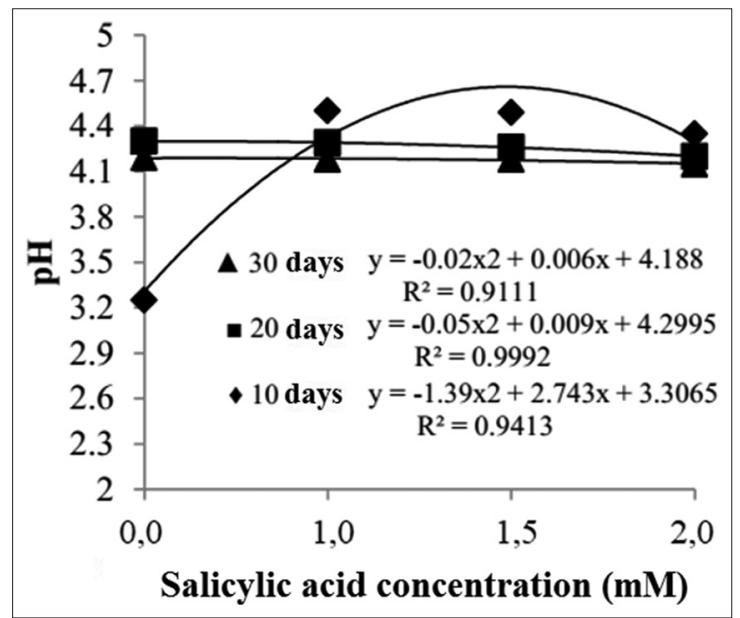

Fig 8. pH of 'Chimarrita' peaches, cycle 2013/2014, treated with different concentrations of salicylic acid - 0,0,1,0, 1,5, and 2,0 mM - and cold storage $-10,20$, and 30 days ( +2 days at $20 \mathrm{C}$ to simulate commercialization), Pelotas/RS - Brazil.

Salicylic acid might induce the production of at least five different protein groups to pathogenicity, such as the chitinase and $\beta-1,3$-glucanase, even in the absence of pathogenicity. (Colli, 2012). These enzymes degrade the polysaccharides in the cell walls of fungi, impairing the development of these microorganisms. Furthermore, salicylic acid induces the expression of genes encoding pathogenesis-related proteins (PR-proteins), what functions as a signaling molecule for systemic acquired resistance (SAR), a type of induced resistance which enhances the plant resistance against subsequent infections and attack of pathogens (Conrath, 2006; Bertocelli et al. 2015).

In soluble solids, an interaction between treatments happened. The values for this variable were higher at 30 days of cold storage (Figure 7), except for the treatments

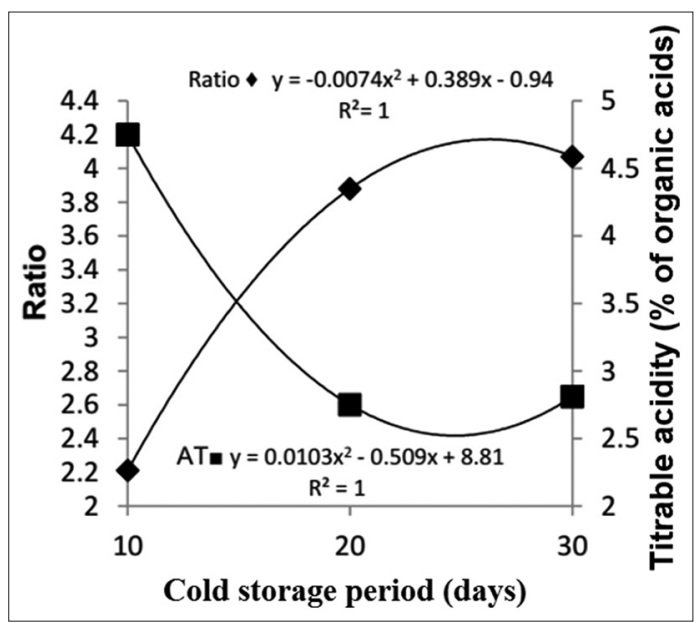

Fig 9. Ratio (\%) and titrable acidity (\% of organic acids) of 'Chimarrita' peaches, harvest 2013/2014, treated with different concentrations of salicylic acid - 0,0, 1,0, 1,5, and 2,0 mM - and cold storage - 10, 20, and 30 days ( +2 days at $20 \mathrm{C}$ to simulate commercialization), Pelotas/ RS - Brazil.

with 2,0 $\mathrm{mM}$ of salicylic acid. Fruits treated with $1,0 \mathrm{mM}$ showed the highest values at all the storage periods. Similar effects were found by Weber et al. (2012), studying passion fruit treated with salicylic acid; a concentration of 1,5 mM reduced the soluble solids. Mazaro et al. (2015) also found that salicylic acid treatments reduced the soluble solids in acerola fruits. The increase in soluble solids is due to the accumulation of sugars, which happens slowly during the development of the fruit and increases substantially after ripening begins (Balbino and Costa, 2003).

The $\mathrm{pH}$ (Figure 8) slightly decreased by increasing the salicylic acid doses and increasing the storage time, with the only remarkable exception of the treatment with $0,0 \mathrm{mM}$ at 10 days. These results are in accordance with results from Silva et al. (2016), which observed lower $\mathrm{pH}$ values in 'Kampai' peaches treated with same referred molecule. $\mathrm{pH}$ is an important variable with respect to food spoilage, because it is directly associated with enzymatic activities and the development of pathogens and its virulence (Neto et al. 2015).

Titrable acidity averages decreased along storage time but were not influenced by salicylic acid doses. The averages ranged from $4,75 \%$ to $2,81 \%$ of organic acids at 10 and 30 days, respectively. Borsatti et al. (2015) did not find significant differences in titrable acidity in black berry treated with salicylic acid and stored cold. Silva et al. (2016) also identified a decrease in titrable acidity of peaches during storage, which was solely associated to storage time, while salicylic acid exerted no effect. This behavior is explained by the ripening process, which also comprises the consumption of organic acids by respiration and its the conversion into sugars (Chitarra and Chitarra, 2005). 
The ratio (Figure 9) was just influenced by the storage period; higher average values were found at longer storage times - 4,07 at 30 days and 2,21 at 10 days. The ratio (ratio total soluble solids/titrable acidity) is commonly used to evaluate the ripeness of fruits, as well as their taste, whose appreciation by humans is mainly determined by the balance between sweetness and acidity (Eskin and Shahidi, 2015; Lima et al., 1999).

A sum of the most remarkable effects is presented next:

- The strongest tendencies associated with salicylic acid were observed in the intermediate concentrations $(1,0$ and $1,5 \mathrm{mM})$ and not in the extremes $(0,0$ and $2 \mathrm{mM})$, what is clear with respect to firmness (at 20 and 30 days), DA index, rot incidence, and soluble solids;

- The concentration of $1 \mathrm{mM}$ of salicylic acid resulted in lower firmness averages - if compared to 0,0 and 2,0 $\mathrm{mM}$, at 20 and 30 days -, the lowest DA index average, the lowest rot incidence average, and the highest average of total soluble solids (sweetness).

- The storage period affected all the analyzed parameters (except rot incidence) and was the only attributable cause to wooliness incidence at 30 days, which was absent earlier, at 10 and 20 days.

\section{CONCLUSION}

The application of salicylic acid solutions at 30 days prior to harvest influenced most of the parameters analyzed in 'Chimarrita' peaches preserved under cold storage up to 30 days $\left(+2\right.$ days at $20^{\circ} \mathrm{C}$ to simulate commercialization), namely: mass loss; firmness; DA index; color ( $\mathrm{a}^{*}, \mathrm{~b}^{*}$, and hue angle); rot incidence; total soluble solids; $\mathrm{pH}$; and ratio. Just the color parameter L, wooliness incidence, and titrable acidity were not affected by the doses of the former compound. The different storage periods affected significantly all the parameters, except rot incidence, which was considerably mitigated by another treatment - around 50\% lower with the salicylic acid treatment at $1 \mathrm{mM}$. The effects of genotype and location could not be covered by this study, what might be a concern for future researches.

\section{Authors' contributions}

This work was carried out in collaboration between all authors. 'Miranda' and 'Lima' wrote the first draft of the manuscript and managed the literature searches. 'Andrade' and 'Schiavon' performed the experiments and participated in fieldwork and laboratory analysis. 'Andrade' and 'Malgarim' designed the study. 'Lemos' wrote the English version and managed the analyses of the study. All authors read and approved the final manuscript.

\section{REFERENCES}

Andrade, S. B., S. P. Galarça, G. R. Gautério, M. B. Malgarim and J. C. Fachinello. 2015. Qualidade de pêssegos das cultivares chimarrita e Maciel sob armazenamento refrigerado em diferentes estádios de maturação na colheita. Rev. Iberoam. Tecnol. Postcosecha. 16: 93-100.

Balbino, J. M. S. and A. F. S. Costa. 2003. Crescimento e desenvolvimento dos frutos do mamoeiro do 'grupo solo' e padrão de qualidade. In: Martins, D. S. and A. F. S. Costa, editors. A Cultura do Mamoeiro: Tecnologias de Produção. ???, Vitória ES. p389-401.

Barreto, C. F., M. B. Moreno, P. S. Silva, M. B. Malgarim and J. C. Fachinello. 2016a. Ácido salicílico na pós-colheita para redução de podridão parda e manutenção qualidade de pêssego 'Chiripá'. Rev. Iberoam. Tecnol. Postcosecha. 17: 50-57.

Barreto, C. F., P.S.Santos, B.M. Marines, C.R.Schiavon, M.B. Malgarim and J. C. Fachinello. 2016b. Armazenamento refrigerado de pêssegos "Maciel" de plantas conduzidas em diferentes portaenxertos. Rev. Iberoam. Tecnol. Postcosecha. 17: 254-261.

Ben-Yehoshua, S. and V. S. Rodov. 2005. Transpiration, water stress. In: Bartz, J. A. and J. K. Brechet. Phosthavest Physiology of Vegetables. $2^{\text {nd }}$ ed. Marcel Dekker, New York.

Bertoncelli, D. J., S. M. Mazaro, R. C. D. Rocha, N. L. Dalacosta, A. Lewandowski and A. W. Junior. 2016. Ácido salicílico na indução de resistência ao tombamento de plântulas de beterraba e atividade antifúngica contra Fusarium $\mathrm{Sp}$, in vitro. Semin. Ciências Agrárias. 37: 67-76.

Borsatti, F. C. 2014. Ácido Salicílico na Qualidade Pós-Colheita de Frutos, Hortaliças Folhosas e Flores. (Master Dissertation) Universidade Tecnológica Federal do Paraná, Pato Branco.

Borsatti, F. C., S. M. Mazaro, M. A. Danner, G. A. Nava and N. L. Dalacosta. 2015. Indução de resistência e qualidade póscolheita de amora-preta tratada com ácido salicílico. Rev. Brasil. Fruticultura. 37: 318-326.

Catinot, J., A, Buchala, E. Abou-Mansour, J. P. Métraux. 2008. Salicylic acid production in response to biotic and abiotic stress depends on isochorismate in Nicotiana benthamiana. FEBS Lett. 582: 473-478.

Cavasini, R. 2013. Inibidores de Etileno na Pós-Colheita de Lisianthus. (Master Dissertation). Faculdade de Ciências Agronômicas da Unesp, Botucatu SP.

Ceagesp[Kindly citethe reference Ceagesp, 2016 in the text part]. 2016. É Tempo de Pêssego Paulista, Suculentos, Gostoso, Colorido. Available from: http://www.ceagesp.gov.br/ comunicacao/noticias/e-tempo-depessego-paulista-suculentogostoso-colorido. [Last accessed on 2017 Jul 21].

Chitarra, M. I. F. and A. B. Chitarra. 2005. Pós-Colheita de Frutas e Hortaliças: Fisiologia e Manuseio. $2^{\text {nd }}$ ed. UFLA, Lavras.

Colli, S. 2012. Outros reguladores: Brassinosteróides, poliaminas, ácidos jasmônico e salicílico. In: Kerbauy, G. B, editor. Fisiologia Vegetal. $2^{\text {nd }}$ ed. Guanabara Koogan, Rio de Janeiro.

Coltro, S., L. Broetto, M. C. C. Rotilli, A. J. D. Moraes, F. K. Barp and G. C. Braga. 2014. Heat shock and salicylic acid on postharvest preservation of organic strawberries. Rev. Ceres. 61: 306-312.

Conrath, U. 2006. Systemic acquired resistance. Plant Signal Behav. 1(4): 179-184. 
Dempseya, D. M. A., A. C. Vlotb, M. C. Wildermuthc and D. Klessiga. 2011. Salicylic acid biosynthesis and metabolism. The Arabidopsis Book. America: American Society of Plant Biologists.

Ding, C. K., C. Y. Wang, K. C. Gross and D. L. Smith. 2001. Reduction of chilling injury and transcript accumulation of heat shock proteins in tomato fruit by methyl jasmonate and methyl salicylate. Plant Sci. 16: 1153-1159.

Eskin, M. N. A. and F. Shahidi. 2015. Bioquímica de Alimentos. $3^{\text {rd }}$ ed. Elsevier, London.

Farias, C. F., M. M. Batalha, P. S. Silva, M. B. Malgarim and J. C. Fachinello. 2016a. Ácido salićlico na pós-colheita para redução de podridão parda e manutenção qualidade de pêssego "chiripá". Rev. Iberoam. Tecnol. Postcosecha. 17: 50-57.

Farias, R. M., C. F. Barreto, M. B. M. Kirinus, S. S. Silva and M. B. Malgarim. 2016b. Crescimento Fúngico Reduz Com Aplicação de Ácido Salicílico na Pós-Colheita de Pêssegos "Chiripá". Revista da Jornada de pós-graduação. 13th Jornada de PósGraduação e Pesquisa Congrega Urcamp.

Ferrareze, J. P. 2014. Jasmonatos e salicilatos e suas funções na defesa das plantas. Available from: https://www.seminariosppgpv. files.wordpress.com/2014/03/aula-jasmonatos-esalicilatos.pdf. [Last accessed on 2017 Jan 26].

Infante, R., M. Farcuh and C. Meneses. 2008. Monitoring the sensorial quality and aroma through an electronic nose in peaches during cold storage. J. Sci. Food Agric. 88: 2073-2078.

Kasat, G. F., B. H. Mattiuz, O. Ogassavara, M. S. Bianco, C. M. Morgado and L. C. J. Cunha. 2007. Injúrias mecânicas e seus efeitos em pêssegos 'Aurora- 1'. Rev. Brasil. Fruticult. 29: 318-322.

Khademi, O., Z. Zamani, Y. Mostofi, S. Kalantari and A. Ahmadi. 2012. Extending storability of persimmon fruit cv. Karaj by postharvest application of salicylic acid. J. Agric. Sci. Technol. 14: 1067-1074.

Khademi, Z. and A. Ershadi. 2013. Postharvest application of salicylic acid improves storability of peach (Prunus persica cv. Elberta) fruits. Int. J. Agric. Crop. Sci. 5: 651-655.

Kerbauy, G. B. 2012. Frutificação e amadurecimento. In: Kerbauy, G. B, editor. Fisiologia Vegetal. 2nd ed. Guanabara Koogan, Rio de Janeiro.

Kluge, R. A., A. A. Picoli and J. S. Aguila. [Kindly cite the reference Kluge, Picoli, Aguila, 2010 in the text part]2010. Respiração e produção de etileno em beterrabas inteiras e minimamente processadas submetidas a tratamentos com etileno e biorreguladores. Rev. Hortic. Bras. 28: 54-57.

Lee, C. Y., V. Kagan, A. W. Jaworski S. K. Brown. 1990. Enzymatic browning in relation to phenolic compounds and polyphenoloxidase activity among various peach cultivars. J. Agric. Food Chem. 38: 99-101.

Lima, L.C., J. A. Giannoni, M. I. F. Chitarra and E. V. B. Boas. 1999. Conservação pós-colheita de pêssegos "premier" sob armazenamento refrigerado. Rev. Ciência Agrotecnol. 23: 303-308.

Loy, F. S., A. Copatti, C. S. Dias, S. B. Andrade and M. B. Malgarim. 2016. Ácido Salicílico e Vida de Prateleira de Pêssegos 'Kampai'. Revista da Jornada de Pós-Graduação e Pesquisa. Congrega URCAMP CD-ROM.

Mazaro, S. M., F. C. Borsatti, N. L, Dalacosta, A. Lewandowski, M. A. Danner, C. Busso and A. W. Junior. 2015. Qualidade pós-colheita de acerolas tratadas com ácido salićlico. Rev. Agrária. 10: 512-517.

Miranda, J., J. Kowaleski, L. G. C. Oliveira and E. A. C. Lima 2017. Ácido Salicílico na Coloração de Frutos de Caquizeiro (Diospyros kaki L). In. Anais FRUSUL Simpósio de Fruticultura da Região Sul.

Neto, A. C. R., M. Maraschin and R. M. Di Piero. 2015. Antifungal activity of salicylic acid against Penicillium expansum and its possible mechanisms of action. Int. J. Food Microbiol. 215; 64-70.

Parisi, M. C. M., C. M. Henrique and P. Prati. 2015. Doenças póscolheita: Um entrave na comercialização. Pesqui. Tecnol. 12: 1-5.[Kindly provide in english language]

Pinheiro, A. D., E. B. Radmann, A. M. Santos, A. Zanella, T. T. Pilar and J. S. Del Aguila. 2014. Conservação da Cultivar de Pêssego Chimarrita em Armazenamento Refrigerado. Anais do Salão Internacional de Ensino, Pesquisa e Extensão. UNIPAMPA, Brazil. p6, 2.

Protas, J. F. S. And J. C. M. Madail. 2003. [Kindly cite reference Protas, Madail, 2003 inthe text part]Características Econômicas e Sociais da Produção de Pêssego no Rio Grande do Sul. Embrapa Uva e Vinho. Available from: https://www.sistemasdeproducao.cnptia. embrapa.br/FontesHTML/Pessego/PessegodeesaRegiaoSerra Gaucha/\%0AEmbrapa. [Last accessed on 2017 Jul 21].

Reisser, J. C., L. C. Timm and V. E. M. Tavares. 2008. Características do Cultivo de PêSsegos da Região de Pelotas-RS, Relacionadas à Disponibilidade de Água Para as Plantas. Documentos 240. Embrapa Clima Temperado, Brasil.

Robaina, A. S. 2013. Avaliação de metil jasmonato e de ácido salicílico no controle pós-colheita de podridões em morango 'Oso Grande'. (Master Dissertation) Instituto Agronômico Campinas.

Rossarolla, M. D., T. C. Tomazetti, A. S. Copatti, A. D. M. Monteiro, P. S. Righi, L. S. H. Aguila and J. A. D. Saavedra. 2012. O ácido salicílico em pré-colheita influencia o controle pós-colheita de Penicillium digitatum de laranja "Salustiana". Rev. Iberoam. Tecnol. Postcosecha. 13: 140-145.

Sasaki, F. F. 2009.Tratamentos Térmicos, Cloreto de Cálcio e Atmosfera Modificada em Pêssegos 'IAC Douradão': Aspectos Fisiológicos, Bioquímicos e de Qualidade. (Doctoral Thesis). Universidade de São Paulo, Escola Superior de Agricultura "Luiz de Queiroz, São Paulo.

Sanches, A. G., M. B. Silva, E. G. S. Moreira and C. A. M. Cordeiro. 2015. Qualidade e resistência pós-colheita de jabuticabas tratadas com ácido salicílico. Acta Iguazu. 4: 28-40.[Kindly provide in english language]

Seyfferth, C. and K. Tsuda. 2014. Salicylic acid signal transduction: The initiation of biosynthesis, perception and transcriptional reprogramming. Front. Plant Sci. 5: 697.

Silva, P. S., C. F. Barreto, M. B. Moreno, M. B. Malgarim and J. C. Fachinello. 2016. Qualidade de Frutos de pêssego "Kampai" submetidos à aplicação de ácido salicílico na pós-colheita. Rev. Iberoam. Tecnol. Postcosecha. 17: 247-253.

Taiz, L., E. Zeigner, I. M. M. Moller and A. Murphy. 2017. Fisiologia e desenvolvimento vegetal. $6^{\text {th }}$ ed. Artmed, Canada.

Weber, D., J. Eloy, G. T. Beskow, M. B. Malgarim, D. A. J. Saavedra and J. C. Fachinello. 2012. Ácido salicílico e refrigeração na conservação de maracujás. Rev. Iberoam. Tecnol. Postcosecha. 13: $123-129$. 